UDK 502/504Thunberg, G. 303.62-057.875 $341.221 .4: 378(497.5)$ https://doi.org/10.31337/oz.76.3.4 Izvorni znanstveni rad Primljeno: 14.9.2020. Prihvaćeno: 25.5.2021.

\title{
The Effect of Internationalization on Students' Attitudes to Environmental Activism
}

\author{
Ivanka Rajh*, Zdravka Biočina**
}

\begin{abstract}
Summary
In 2019 Greta Thunberg gave a speech at the UN Climate Action Summit on climate change. The survey presented in this paper was conducted among students studying at the Zagreb School of Economics and Management $(N=99)$ in order to analyze their attitudes to this speech. The sample included students from Croatia as well as international students. Research questions covered the role of language, ecological awareness, age and education in the perception of the quality, the attractiveness of the speech, the use of ethos, pathos and logos, persuasiveness, and also influence potential. Generally, the results show statistically significant differences in perception and attitude between Croatian and international students.
\end{abstract}

Key words: internationalization of universities; environmental activism; student attitudes; student perceptions; Greta Thunberg; public speaking

\section{Introduction}

New studies and initiatives aim to bring the discourse on climate change to young generations through schools and democratic activism (Hodson, 2014; Reis, 2020). This is especially important since studies show that some social groups are less prone to pro-environmental behaviour. Among these groups are young adults (Steel, 1996; TNS Opinion \& Social, 2011). That is not the case for one very famous teenager - Greta Thunberg. In 2019, Greta Thunberg gave a speech at the UN Climate Action Summit that sparked great attention as well as numerous controversies in the global media. The first controversy results from the formality of the venue and the audience present and the second from the

* Ivanka Rajh, Ph.D., Senior Assistant Professor, Zagreb School of Economics and Management. Address: Vukasovićeva ulica 1, 10000 Zagreb, Croatia. ORCID iD: https://orcid.org/0000-00025109-5797. E-mail: irajh@zsem.hr

** Zdravka Biočina, Ph.D., Zagreb School of Economics and Management. Address: Vukasovićeva ulica 1, 10000 Zagreb, Croatia. ORCID iD: https://orcid.org/0000-0002-8262-9528.

E-mail: zbiocina@zsem.hr 
speaker: a young girl with Asperger syndrome who is also a non-expert. However, her credibility as a speaker at that summit is a pre-discursive one - i.e. she was known in public for her activism before the UN Summit. At the age of only 15 years, in August 2018, she planned a strike at school and a protest outside the Swedish parliament, urging politicians to do more about global warming prevention. By doing this, and with the help of social media, she gained global attention and encouraged others to talk more about climate change. Her discursive ethos (established through the speech (Amossy, 2000)) and influence on young adults were studied among students at the Zagreb School of Economics and Management.

Namely, when the speech was analyzed in second-year Rhetoric classes, it was noticed that groups studying in the Croatian language differed from groups studying in English in their attitudes toward the teen activist Greta Thunberg and her speech at the UN Climate Action Summit. This motivated us to conduct a survey among students at the Zagreb School of Economics and Management in order to analyze their attitudes to the speech and the speaker and to detect potential reasons for differences. Furthermore, the relation between their self-assessed environmental behaviour and their attitudes about the speech was analyzed.

Our first assumption was that the difference arises from the fact that students from countries of the developed world ${ }^{1}$ have a more positive attitude to (environmental) activism compared to domestic students since civic education in Croatia is only in its initial stage. Additionally, our experience has shown that students who decide to participate in the exchange program are generally more ambitious, proactive and open to new ideas than those who do not, which may also affect their attitude to activists and activism. The Zagreb School of Economics and Management prides itself on providing international experience at home and abroad, thus preparing its students for »long term success in a globalized business world « (ZSEM, 2021). Therefore, our second assumption was that domestic students who embrace the international environment at ZSEM, by enrolling in the English program and studying alongside the exchange students, may have a more positive attitude to (environmental) activism than those enrolling in the Croatian program.

The first part of the paper covers the topics of internationalization of universities and environmental activism in order to detect possible implications for the attitudes of the research subjects. The second part of the paper presents research conducted among students at the Zagreb School of Economics and Management and discusses the results with the aim of further enhancing the ZSEM curriculum. The overall aim of the research is to detect the benefits of studying in an international environment that go beyond the personal experience of traveling and studying abroad, one of which may be a greater openness to civic ideas and a common understanding of global issues.

1 E.g. as defined by the UN's Country Classification (United Nations, 2019). 


\section{Literature Review}

\subsection{Internationalization of universities}

Higher education has always been international in the sense that scholars, students, and consequently knowledge, move to and between the great university centers of the world; however, globalization has transformed higher education in unprecedented new ways. A rapid development of the two most important technologies that facilitate global convergence of industries and markets, namely transportation and communication, has enabled access to international higher education - previously reserved for cultural and social elites - to ordinary citizens, due to faster and cheaper travel and communication networks. For universities, globalization also means that education has become a tradable commodity on the open market, pushing them to compete for human and financial resources as well as recognition worldwide. The globalization of higher education is a consequence or the goal of different internationalization strategies applied by universities around the world (Wit, 2011; Mitchell and Nielsen, 2012).

The most commonly cited definition of "internationalization" is that by Knight (2008, 21): »the process of integrating an international, intercultural, or global dimension into the purpose, functions or delivery of post-secondary education. «In a comprehensive overview of internationalization trends and student mobility as a traditional key feature of internationalization, Teichler $(2017,186)$ points out that absolute figures of around 4 million students studying abroad, as reported in recent literature, are misleading due to different definitions and statistical criteria; also, that the proportion of such students has remained »constant at about $2 \%$ or slightly more «. Apart from student mobility, internationalization also includes international cooperation and partnerships, mobility and migration of scholars, provision of study programs in other countries, e-learning across borders, and the »internationalization at home « phenomenon. The latter is often seen as a subordinate or an element of a wider concept which is the internationalization of the curriculum: »Internationalization of the curriculum is the incorporation of international, intercultural, and/or global dimensions into the content of the curriculum as well as the learning outcomes, assessment tasks, teaching methods, and support services of a program of study « (Leask, 2015, 9). According to Beelen and Jones $(2015,69)$, »internationalization at home (IaH) is the purposeful integration of international and intercultural dimensions into the formal and informal curriculum for all students within domestic learning environments «. IaH does not assume the presence of international students or teachers in the classroom, nor English as the language of instruction, but includes international literature, guest lectures, case studies and practice, digital learning, and on-line collaboration. IaH might prove crucial for those students who, despite the internationalization of the classroom, campus and the curriculum, do not see the benefits of international engagement for their future careers (Harrison, 2019). 
As stated in the introduction, ZSEM is highly committed to providing international experience to its students. ZSEM students have the opportunity to study at one of 150 partner institutions around the world, while at the same time incoming students contribute to the international experience on the ZSEM campus. The first international students arrived at ZSEM in 2006, and their numbers have been growing constantly ever since. The average number of incoming students per academic year, both for the exchange and the summer school programs, since 2014/2015 has been around 280, while in the academic year relevant for this research, i.e. 2019/2020, there was a total of 233 incoming students (ZSEM internal data). ${ }^{2}$ In comparison, the total number of incoming students to Croatia in the academic year 2018/2019 was 2552, according to the latest Erasmus + report (European Commission, 2020), meaning that almost $10 \%$ of those students chose ZSEM.

\subsection{Attitudes to environmental activism}

As regards the incorporation of international or global topics for the internationalization of a curriculum, global warming and other environmental issues are among the most obvious candidates, as both the effects and (global) policies thereof affect the everyday lives of people around the world. The following paragraphs provide a brief overview of how environmental issues have gradually permeated academic and general public debates.

Public discourse and concern for the environment have been intensifying from the 1970s onwards (Johansson, 1995, 319 in Ester et al., 2004, 47). Some evidence for this are the numerous »surveys, conducted by both commercial polling agencies and independent groups of academic social scientists, measuring public attitudes toward environmental issues « (Ester et al., 2004, 45). One of these is the Global Environmental Survey (GOES) that measures the impact of cultural influences on environmental attitudes. It is a large-scale survey that includes a cross-national corpus on which it examines people's environmental concerns, attitudes, and behaviour. Additionally, the survey shows how leading environmental decision-makers use knowledge on public opinion and environmental behaviour in creating policies. The researchers found a discrepancy between attitudes to pro-environmental behaviour and citizens' environmental involvement and commitment (Ester et al., 2004).

Surveys on environmental behaviours and attitudes of the public are very important as they reveal public opinion and the great polarization of society in regard to attitudes on climate change. Fielding and Hornsey (2016) think that this is a problem because, »despite being one of the most important environmental challenges of our time, progress on developing effective policies and targets to mitigate climate change has been slow, in part because of the skepticism of segments of society, usually ideological conservatives, who question the reality or anthropogenic basis of climate change (Fielding and Hornsey, 2016, 1-2). Also,

2 As reported to the Ministry of Science and Education. 
environmental behaviour and support of a particular environmental action or policy of the citizens may be affected by group membership, which need not be only political, e.g. left and right/liberal and conservative (Steel, 1996; Fielding and Hornsey, 2016). For instance, Steel (1996) found that persons with higher education are more likely to participate in environmentally protective behaviours and policy issues. Furthermore, women are significantly more environmentally proactive than men and gender differences in environmental behaviour are increasing with age (Steel, 1996). Steel $(1996,34)$ explains this discrepancy between genders with the more traditional roles that women had, especially in the past, in maintaining the household and doing chores like buying food, sorting garbage, etc., which is an example of pro-environmental behaviour. A recent Eurobarometer survey also confirmed that older age groups are more engaged in pro-environmental behaviour than younger groups (TNS Opinion \& Social, 2011).

Due to this age factor, a lot of research is done on how to include young people in pro-environmental behaviour. One way is through activism which has an educational value for youth since it develops their critical thinking and scientific literacy (Reis, 2020; Hodson, 2011), especially if we look at it as a »process of collective, democratic, research-informed and negotiated problem-solving action on socio-environmental problems « (Reis, 2020, 140). Reis quotes numerous studies that show how students' activism on environmental issues has benefits for their knowledge, communication skills, critical thinking skills and argumentation, citizenship competences, creativity, etc. Hodson (2014) sees education as a key component that can spur engagement among youth through the promotion of democratic activism. However, to accomplish the greater involvement of younger people, schools and communities have to work together (Hodson, 2014).

One of the most prominent figures of youth activism in the field of environment (but also in general) is Greta Thunberg. Reis $(2020,143)$ singles out Greta Thunberg as a »great example of youth activism spread by social media «. With the use of social media she was able to raise climate change awareness among younger people from different countries, but also to urge action on this issue among people of influence. Through her initiative, she mobilized people around the globe but also encouraged other teen activists.

Youth engagement in activism is crucial for Education for Environmental Citizenship (ENEC 2018). »Through activism, students move from a position of learning to a new position of engagement in acts of citizenship and practices of scientific inquiry. Students are therefore empowered as producers of contextualized and socially relevant knowledge, instead of being simple consumers of knowledge « (Reis, 2020, 144). By studying students' behaviour and attitudes on climate change we can learn more about how to engage them actively in environmental citizenship. 


\section{Research}

In this chapter, we firstly discuss the sample, which has its limitations as it is specific for ZSEM and as such very different from what one could expect to find at other higher education institutions in Croatia considering the number of international students in the classroom. Next, we introduce the research questions and hypothesis, and finally the research methods.

\subsection{Sample}

The sample was made up of a total of 99 students divided into two groups. The Croatian group consisted of 35 students enrolled in the Croatian program of studies, and the English group consisted of 64 students. While the Croatian group was quite homogenous with $95 \%$ students being first-year students at the time of the survey, the English group was very heterogeneous as can be seen in the Table 1 below.

Table 1. Composition of the English group

Tablica 1. Sastav engleske grupe

\begin{tabular}{|l|c|c|c|c|c|c|}
\hline English group & $1^{\text {st }}$ year & $2^{\text {nd }}$ year & $3^{\text {rd }}$ year & $4^{\text {th }}$ year & $5^{\text {th }}$ year & Total \\
\hline $\begin{array}{l}\text { Croatian } \\
\text { students }\end{array}$ & $8(22 \%)$ & $28(76 \%)$ & $1(2 \%)$ & & & 37 \\
\hline $\begin{array}{l}\text { International } \\
\text { students }\end{array}$ & $5(18 \%)$ & $11(40 \%)$ & $6(22 \%)$ & $5(18 \%)$ & $1(2 \%)$ & 27 \\
\hline
\end{tabular}

A large part of the English group students $(\mathrm{N}=37)$ were students from Croatia who enrolled in the English program of studies and were mostly second year students at the time of the survey, while the rest of the group was made up of international students $(\mathrm{N}=27)$ who came to study in Croatia for one semester or longer. The international subgroup was not heterogeneous only in regard to the year of study but also the country of origin, whereby $60 \%$ of students came from developed countries (Australia, USA, France, Japan, South Korea, Italy, Slovenia, and Germany), 18\% from developing countries (China, Kenya), while the remaining $22 \%$ did not specify their country of origin.

While the Economics and Management study program is the same for all ZSEM students, students have the opportunity to choose to study in Croatian or English. Studying in English means that students are necessarily going to be a part of an international class as all foreign students who do not speak Croatian are placed in that program. This means that, apart from studying in English, which is a global language used by the business community around the world, they are also going to be interacting with students of different cultural and ethnic origins.

The choice between study programs may be motivated by different attitudes to global citizenship as proposed by Harrison (2019, 13-14). Global activists have 
an interest in diversity and global issues, such as poverty, climate change, and human rights, and are motivated to cooperate with students from other cultures. Global workers have an instrumental view of competence in intercultural relations as a transferable skill to be developed. Home aloners do not expect an international career, are not engaged in global issues, and may have passive or even negative views on diversity. Belonging to either of the three types may be conditioned by earlier experiences which may or may not have included global issues or cultural diversity. Furthermore, the types are not fixed over time and individuals may move between the groups depending on new experiences and consequent changes in their value systems.

The above considerations should be taken into account while evaluating the responses of our sample. While we do not have the exact information on why some Croatian students have chosen to enroll into the ZSEM English program rather than the program in the Croatian language, we know from our experience that many of them have previously attended either bilingual or IB high-school programs; some grew up abroad or have attended international schools, and others see this as an opportunity to perfect their English language skills, which will help them later on in studying or working abroad. According to the above observations by Harrison (2019), their choice of a study program may have been motivated by attitudes at the time of enrolment, but depending on their further experience, in this case of the ZSEM international setting, their attitudes to global issues may change.

\subsection{Research questions and hypothesis}

As explained at the outset, in discussions on Greta Thunberg's speech at the UN Climate Action Summit, differences arose between the students studying in Croatian (the Croatian group) and those studying in English (the English group). Taking into account our assumptions, three sets of research questions were formulated:

a) To what extent do the Croatian and English groups differ in their attitudes to Greta and her speech? Is this difference statistically significant?

b) Is there a statistically significant difference between Croatian and international students within the English group in their attitudes to Greta and her speech?

c) Can differences in attitudes between Croatian and English groups to the speech and the speaker be linked to their self-assessed environmental behaviour?

Taking into account the overview of relevant literature and the research questions above, the following hypotheses were proposed:

H1: There will be a statistically significant difference between the Croatian and the English groups of students regarding their attitudes towards Greta Thunberg and her speech.

$\mathrm{H} 2$ : There will not be a statistically significant difference between Croatian and international students within the English group regarding their attitudes towards Greta Thunberg and her speech. 
H3: The group which, at the beginning of the survey, assesses itself as ecologically more aware will assign Greta and her speech higher grades on the Likert scale.

\subsection{Research methods}

After a brief introduction to the topic, the students watched Greta Thunberg's speech at the UN Climate Action Summit in New York City on September 23, 2019, after which they were asked to fill in an on-line questionnaire.

The majority of students were quite familiar with the work of the teenage activist Greta Thunberg, who started a series of »school strikes for climate « which attracted masses of young people especially in Western Europe, North America, and Australia. Greta's UN speech was widely publicized and discussed across the global media, and thus represents a truly international or global topic incorporated into the ZSEM communication courses.

The questionnaire consisted of 15 questions divided into three topics: demographic questions, attitudes towards environmental issues, and evaluation of Greta Thunberg's speech. The Croatian group of students was administered the questionnaire in Croatian, while the international group received the questionnaire in the English language. There were two types of questions. In the first set of questions the attitudes were measured against the Likert scale. The second set consisted of yes/no questions.

The experiment was conducted during Business Communication and Rhetoric classes for each group in December 2019. The students first watched a video of the speech and were then administered the questionnaire via Google Forms.

\subsection{Statistical analysis}

Statistical analysis was conducted using Microsoft Excel. The idea was to check whether there is a statistically significant difference in the answers of students studying in Croatian as opposed to those studying in English. For the purpose of testing differences between the population mean, a t-test for unknown population variances was performed. An F-test was done to determine the equality of population variances. This is a t-test where population variances are unknown but are assumed to be equal. The F-test showed that there is no difference between population variances in regard to all the questions from the survey. The t-test was used to test the differences between the responses of the Croatian and the English groups for each question. The differences between international students and Croatian students within the English group were also calculated.

\section{Results and Discussion}

For this paper, we focused on seven questions regarding the students' perceptions of the naturalness, persuasiveness, and attractiveness of Greta's speech, their assessment of Greta's use of rhetorical appeals as well as to the assessment of their ecological awareness and behaviour. 


\subsection{Ecological awareness}

As can be seen in Figure 1 above, there is a slightly greater proportion of English group students which self-assess as having high or very high ecological awareness $(34.5 \%)$ as compared to the Croatian group (28.6\%), as well as those with moderate ecological awareness (62.5\% vs. 54.3\%). This slightly higher ecological awareness of the English group is not statistically significant (p-value $=0.563$ ). Furthermore, differences within the English group, between Croatian and international students were also not statistically significant for this question $(\mathrm{p}-\mathrm{value}=0.306)$. Previous research (Ester et al., 2004) implies that in developing countries, people are more preoccupied with existential problems, and that economic prosperity is needed for people to be more perceptive of environmental issues. Today, Croatia is classified as a developed country, but it is still less developed and poorer compared to the developed countries from which the international students come.

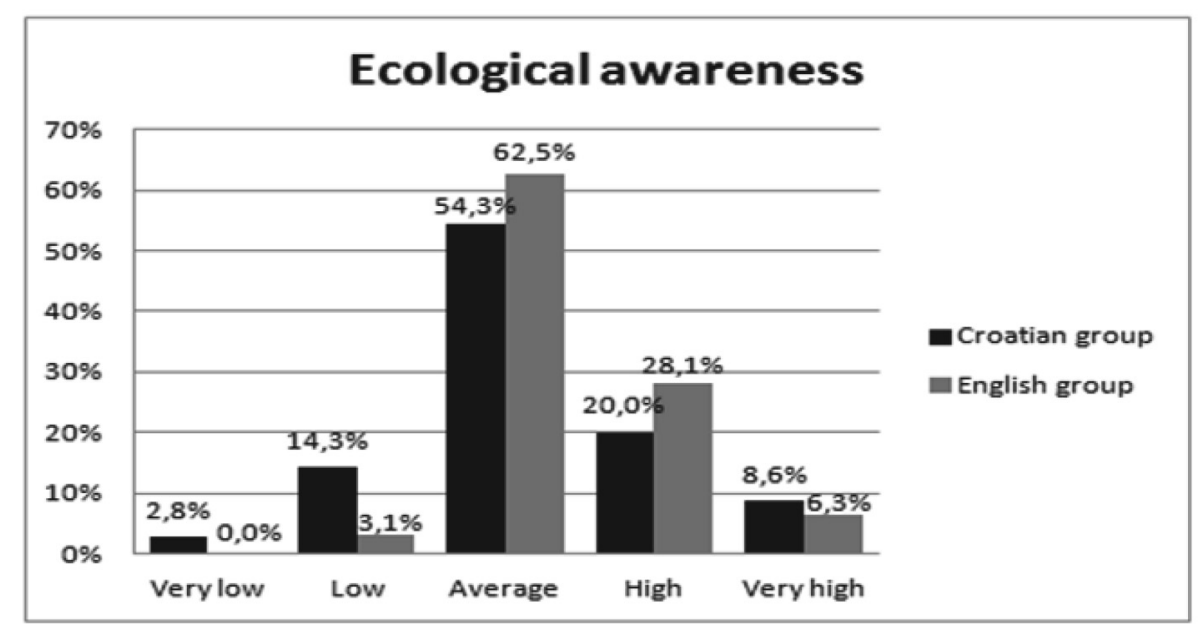

Graph 1. Assess your ecological awareness on a scale from 1 (not at all) to 5 (fully) Grafikon 1. Ocijenite koliko ste ekološki osviješteni na ljestvici od 1 (nimalo) do 5 (u potpunosti)

It is worth pointing out that a self-assessment of ecological awareness is a very complex task. Fielding and Hornsey $(2016,5)$ discovered that $»$ participants' environmental values, intentions and behavioural choices shifted in line with the national stereotype «. Authors give the example of Great Britain and the United States. When citizens from Great Britain assess their ecological awareness, they consider themselves more ecologically aware as compared to United States citizens. The same pattern is found to be true for students. When a group of students compare their behaviour with that of the previous generation, they perceive current students as pro-environmental, but when they compare them with future generations, they find current students as less pro-environmental (Fielding and 
Hornsey, 2016). Also, Ester et al. (2004) showed that the practice of one type of ecologically conscious behaviour does not predict engagement in another. So, when participants are assessing themselves, we cannot know which pro-environmental behaviour they have in mind.

\subsection{Evaluation of Greta's speech}

As many as $57.2 \%$ of the students from the Croatian group assess the naturalness of Greta's speech as being very low or low compared to $34.4 \%$ of the students from the English group. Accordingly, 39\% of the students from the English group consider her naturalness to be high or very high compared to only $22.9 \%$ from the Croatian group. This difference is not statistically significant between groups ( $\mathrm{p}-\mathrm{value}=0.339$ ), even though the mean of the English group is higher than that of the Croatian group. On the other hand, differences within the English group are statistically significant $(\mathrm{p}$-value $=0.004)$ : international students gave Greta's speech a significantly higher grade for naturalness in comparison to Croatian students from the same group.

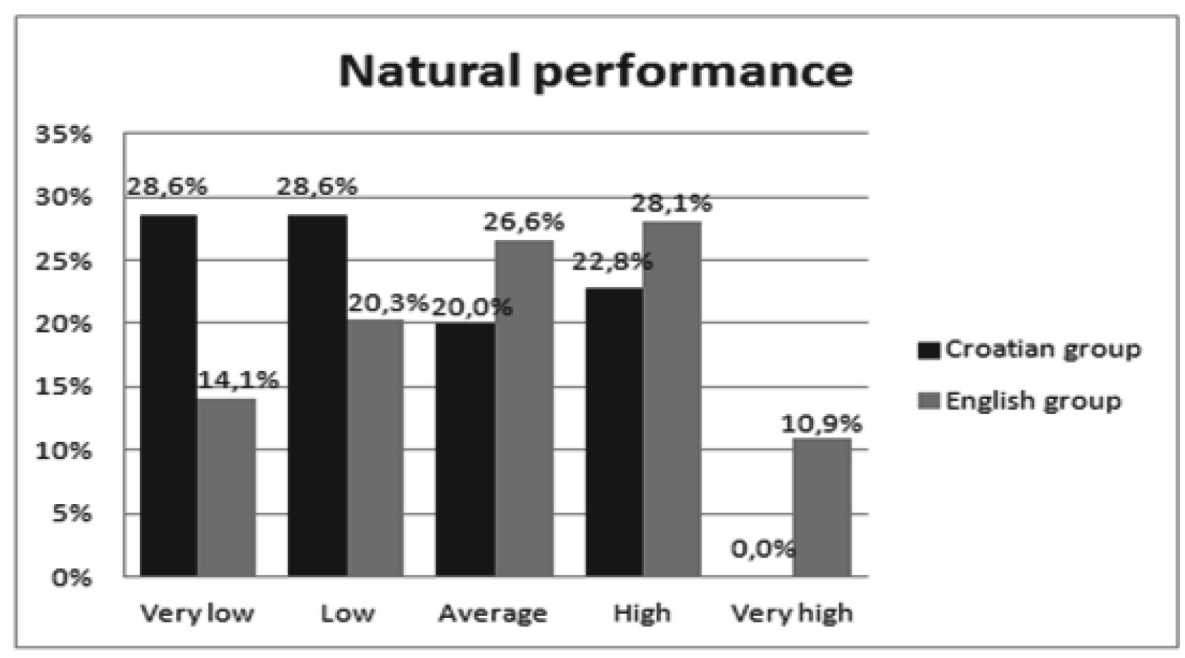

Graph 2. Assess the naturalness of Greta's performance on a scale from 1 (not at all) to 5 (completely)

Grafikon 2. Ocijenite koliko je prirodna bila njezina govorna izvedba na ljestvici od 1 (nimalo) do 5 (u potpunosti) 


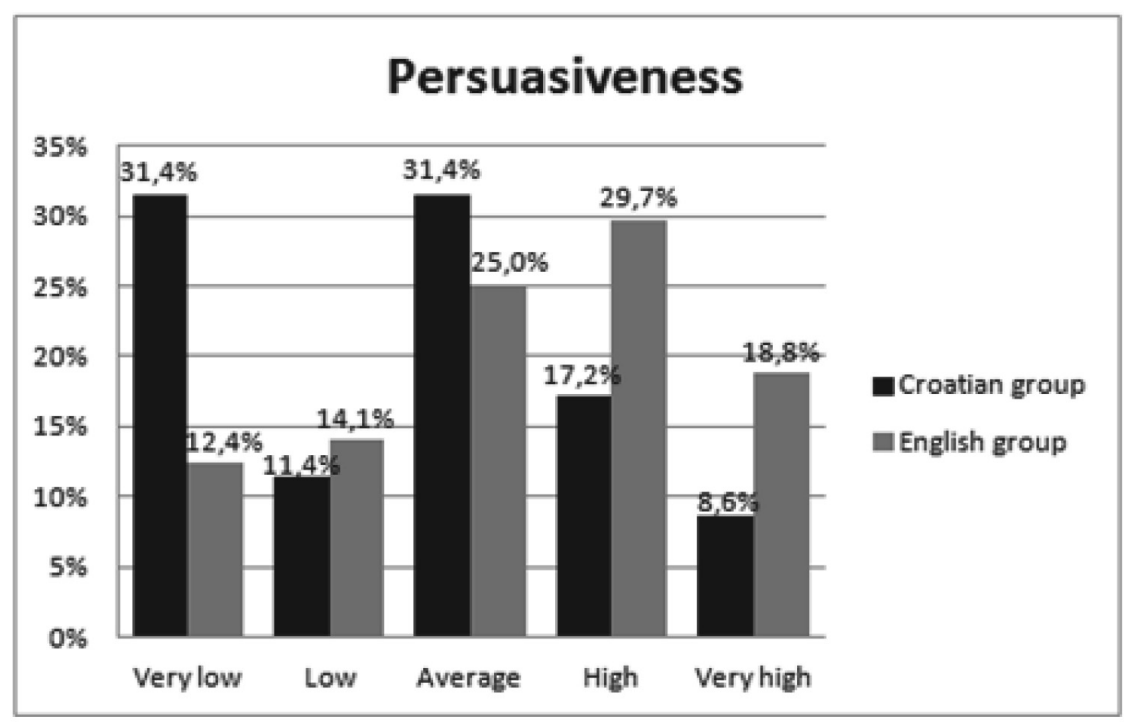

Graph 3. Assess the persuasiveness of Greta's message on a scale from 1 (not at all) to 5 (completely)

Grafikon 3. Koliko vam je bila uvjerljiva njezina poruka na ljestvici od 1 (nimalo) do 5 (u potpunosti)?

Even though only $25.7 \%$ of the students from the Croatian group consider Greta Thunberg's speech to be persuasive compared to $48.5 \%$ of the English group, the difference is not statistically significant ( $\mathrm{p}-$ value $=0.312$ ). Then again, the difference is statistically significant between Croatian students and international students in the English group ( $\mathrm{p}$-value $=0.006$ ). We can conclude that on average students do not consider her very persuasive. Why is this so? Already Aristotle in his time wrote about modes of persuasion, also known as rhetorical appeals. According to his classification, the persuasiveness of a speech can be achieved through ethos, pathos or logos (Aristotle, 1989). In short, ethos is related to the speaker's character, pathos to the emotions that the speaker evokes in his or her audience, and logos to the speaker's argumentation. When other results of this survey are taken into account, it can be seen that respondents think the speaker has convincing arguments, i.e. logos, but many do not consider her to have the credibility to speak at such a forum nor do they like her emotional performance. This is especially true for the Croatian students and is reflected in the above result. 


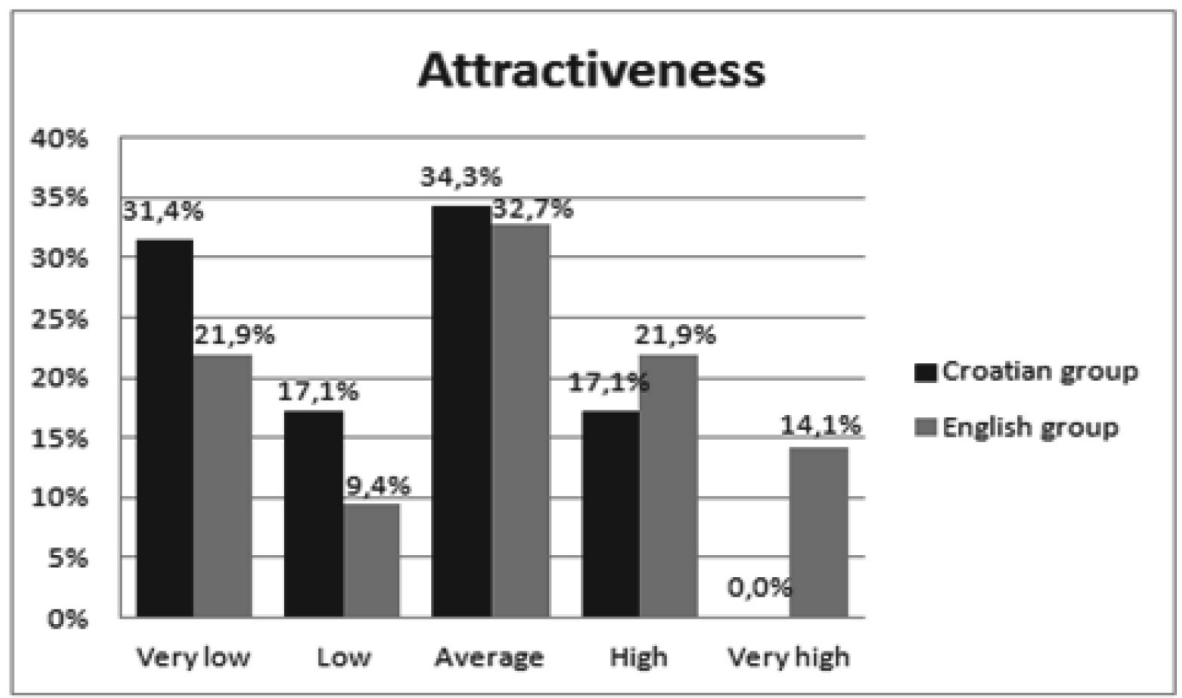

Graph 4. How did you like her speech on a scale from not at all (very low attractiveness) to very much (very high attractiveness)?

Grafikon 4. Koliko Vam se svidio njezin govor na ljestvici od 1 (nimalo) do 5 (u potpunosti)?

Almost half of the students from the Croatian group (48.5\%) did not like Greta's speech, as opposed to $36 \%$ of those from the English group who liked it a lot or extremely. The t-test showed that there is a statistically significant difference between these two groups $(p-$ value $=0.032$ ) regarding the responses to this question. Furthermore, differences within the English group were also tested. Results show that international students gave the speech significantly higher grades for attractiveness than Croatian students, the difference being statistically significant $(\mathrm{p}-\mathrm{value}=0.0001)$. It is hard to say where this aversion of Croatian students towards Greta's speech comes from. According to Zoričić (2018), online media are the primary source of information for young people in Croatia. A quick overview of articles on Greta Thunberg published in the top on-line media mentioned by Zoričić (Index.hr, 24sata.hr, Jutarnji.hr) suggests that the Croatian media reported on Greta in a neutral or positive tone; however, due to the time-lapse, it was not possible to analyze the comments below the articles which are often quite extreme and which may influence the opinions of young people. The same applies to comments from social networks which are the top sources of information for young Croats and are used on a daily basis. 


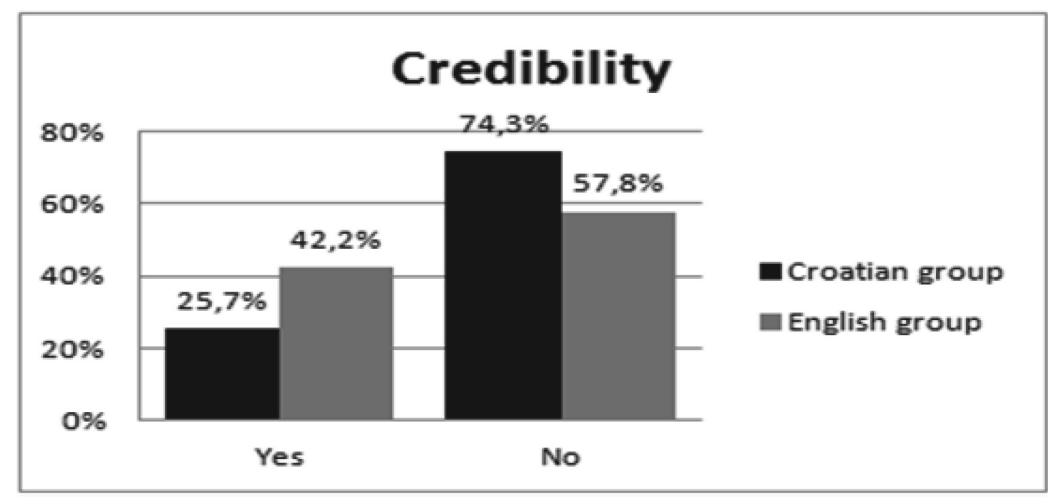

Graph 5. Does Greta Thunberg have credibility as a speaker at the UN summit? Grafikon 5. Ima li Greta Thunberg kredibilitet kao govornik na summitu UN-a?

As shown in Figure 5, the Croatian group found Greta Thunberg less credible as a speaker at the UN summit then the English group. The statistical analysis of the results found that this difference is statistically significant ( $\mathrm{p}$-value $=$ 0.044). The contingency table has shown that there is a connection between the students' response and their belonging to a particular group. This is also true for subgroups within the English group. Results showed that there is a difference between the population proportion of international students and Croatian students in the English group, and that it is larger for the international students (80\% vs. $20 \%$ ). This difference is statistically significant ( $\mathrm{p}-\mathrm{value}=0.00004)$. Furthermore, if we test the difference between the population proportion of Croatian students studying in English and Croatian students studying in Croatian, there is no statistically significant difference for responses to this question.

The explanation for the above results may lie in the following. According to Amossy (2000), there are two types, namely, pre-discursive and discursive (speaking) ethos or credibility. Pre-discursive ethos is the image of the speaker that the audience creates before the speech based on existing information about the speaker (Amossy, 2000, 7). Discursive ethos is the one gained in the course of the speech. Since Greta was known for her pro-environmental activism even before the UN summit, we can say that she earned the credibility to give a speech at this important occasion. Since both groups in the second year of their studies at ZSEM take a Rhetoric course in which they learn about the speaker's credibility or ethos, we can only conclude that they were not completely aware of Greta's previous activism. One other reason may be her age since, in Croatia, the age hierarchy is still strong, meaning that children and young people are not taken seriously. 


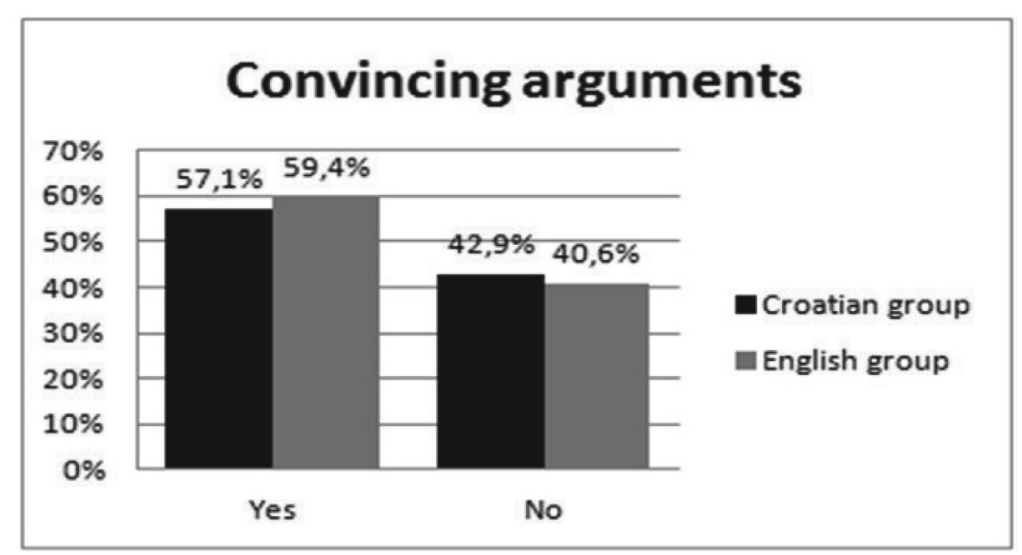

Graph 6. Was the speech supported by convincing arguments?

Grafikon 6. Je li govor bio potkrijepljen uvjerljivim argumentima?

Considering that students from the Croatian group gave, on the average, lower scores to Greta's speech for naturalness, persuasiveness, attractiveness, and credibility, it is surprising that students from both groups agree to a high degree $(57.1 \%$ and $59.4 \%)$ that her speech contained convincing arguments. While there was no statistically significant difference regarding this question between the English and the Croatian group ( $\mathrm{p}$-value $=0.241$ ), there was a statistically significant difference within the English group $(\mathrm{p}$-value $=0.043)$, where a significantly greater number of international students gave a positive response to this question compared to Croatian students within the group. Regarding convincing arguments, Greta used mostly topoi that are already accepted in society, especially among a highly-educated audience. What is interesting, however, is the fact that Croatian students found her much less persuasive, even though they found her arguments convincing. An explanation for this may lie in her performance which was very emotional and was in contradiction to her strong argumentation. This imbalance between the logical content and her overly emotional performance may be the reason why students assigned lower grades to the naturalness of her performance.

\subsection{Willingness to change}

Figure 7 above shows that more than $85 \%$ of the students in the Croatian group (as opposed to less than $60 \%$ in the English group) would not be willing to change their behaviour as a result of listening to Greta's speech. Even though this difference is not statistically significant between the groups ( $p$-value $=0.198$ ), it is significant in the English group between international students and Croatian students $(\mathrm{p}$-value $=0.033)$. Together with results obtained for other questions, it may imply that among Croatian students there are more home aloners. Home aloners, according to Harrison (2019), are not engaged in global issues and may have an ethnocentric outlook. 


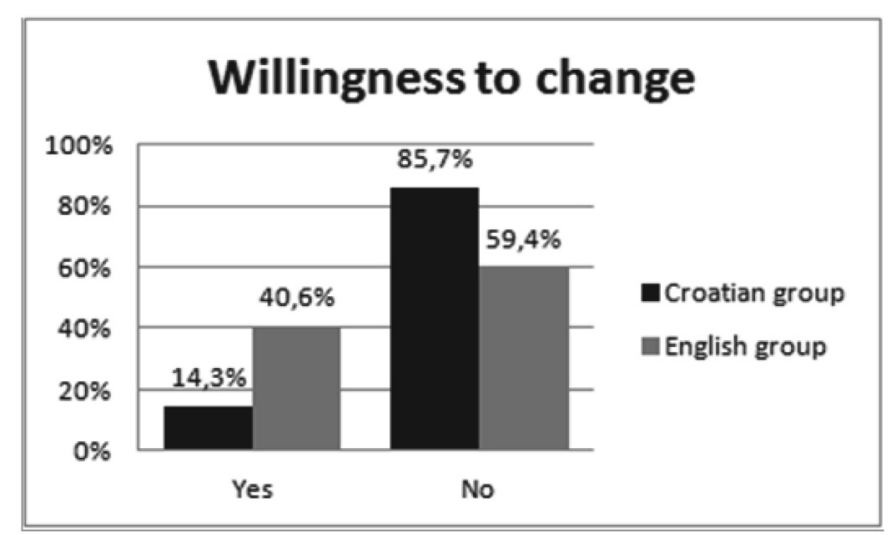

Graph 7. Would you change your behaviour as a result of listening to her speech? Grafikon 7. Biste li zbog njezina govora promijenili svoje ponašanje?

Interestingly, the statistical analysis found significant differences between genders regarding the responses to at least two questions. The results showed that female students gave higher grades to Greta and her speech for attractiveness, and that they would be more willing to change their behaviour as a result of listening to Greta's speech. This may be due to the fact that the speaker and the female students are of the same gender, as some studies show (e.g. Turman and Barton, 2004; Langan et al., 2005). As gender differences were not a focus of this study, further research should look into how gender affects the perception of speakers and environmental issues.

To sum up, even though students in the English group self-assess as just slightly more ecologically aware than those in the Croatian group (34.5\% vs. $28.6 \%$ ), they assign to Greta's speech higher grades than the Croatian group, and this is so across all categories: naturalness (39\% vs. $22.9 \%)$, persuasiveness ( $48.5 \%$ vs. $25.7 \%$ ), attractiveness ( $36 \%$ vs. $17 \%$ ), and credibility (42\% vs. $25.7 \%$ ). A greater percentage of students from the English group would also change their behaviour owing to Greta's speech ( $40.6 \%$ vs. $14.3 \%)$. However, a further statistical analysis showed that this difference between the English and the Croatian groups is statistically significant only for the assessment of the attractiveness of the speech and the credibility of the speaker (Table 2). Nevertheless, statistically significant differences regarding assessment and attitudes to Greta's speech were also found within the English group, with international students generally assigning higher grades than Croatian students. 
Table 2. Statistical significance of the results

Tablica 2. Statistički značajne razlike rezultata

\begin{tabular}{|l|c|c|}
\hline \multicolumn{1}{|c|}{ Criterion } & $\begin{array}{c}\text { Statistically significant } \\
\text { difference between the } \\
\text { English and the Croatian } \\
\text { group }\end{array}$ & $\begin{array}{c}\text { Statistically significant } \\
\text { difference within } \\
\text { the English group, } \\
\text { between Croatian and } \\
\text { international students }\end{array}$ \\
\hline Ecological awareness & NO & NO \\
\hline Naturalness & NO & YES \\
\hline Persuasiveness & NO & YES \\
\hline Attractiveness & YES & YES \\
\hline Credibility & YES & YES \\
\hline Convincing arguments & NO & YES \\
\hline Willingness to change & NO & YES \\
\hline
\end{tabular}

Therefore, we can conclude that our first hypothesis was proven only partially correct, i.e. the difference between the Croatian and English groups in attitudes to Greta's speech was statistically significant only for two criteria (attractiveness and credibility). Our second hypothesis, namely, that there will not be a statistically significant difference between Croatian and international students within the English groups regarding their attitudes towards Greta Thunberg and her speech, was not validated since statistically significant differences were found between Croatian and international students within the English group for the above criteria. Our third hypothesis, namely, that the group which, at the beginning of the survey, assesses itself as ecologically more aware will assign Greta and her speech higher grades on the Likert scale, proved to be partially correct. Namely, the difference between the English and the Croatian group regarding self-assessed ecological awareness was not (statistically) significant, with the English group assessing itself as only slightly more ecologically aware than the Croatian group. However, international students in the English group generally assigned Greta higher grades than Croatian students. As we mentioned earlier, self-assessment of ecological awareness is a very complex task and does not predict a specific type of ecologically conscious behaviour (Fielding and Hornsey, 2016; Ester et al., 2004).

What does all of this tell us about the one or the other group of ZSEM students? The internationalization of universities and the curriculum does not imply that students from different countries will have the same or similar stance to global topics, such as global warming. Even though students from the Croatian group were well-informed about Greta Thunberg, and maybe even participated in school strikes for climate, they still did not think she was credible enough to speak at an international political forum. Their attitude may be affected by the fact that global warming is still not as important a topic in Croatian public dis- 
course as are the national economic or political situation, or that they are simply not interested in global issues, for which reason we could classify them among the home aloners according to Harrison's typology (2019, 13-14). On the other hand, the English group of students may generally be composed of a greater proportion of students whom Harrison defined as global activists, and who are interested in global issues such as climate change. However, a great proportion of Croatian students in the English group are, according to statistical tests, simply global workers with an instrumental view of intercultural competences. Among the three groups, it is the global activists whom we expect to believe that young people, despite their age, origin, social status or lack of experience, can contribute to solving global issues and bring about change at the international level. Depending on their local cultural and political traditions, students may also find it more or less natural for persons of their age to actively engage in social issues.

As was pointed out at the beginning of this section, the sample for this survey was unique to the Zagreb School of Economics and Management. Further research should include a larger sample of students from other higher education institutions in Croatia, and among other variables, focus on gender differences in student attitudes to environmental activism.

\section{Conclusion}

The introduction of global topics into the curriculum to internationalize higher education may be sufficient at the level of expanding students' knowledge and awareness of international issues. However, if we aim at achieving international agreement or bringing closer together diverse attitudes to global issues, the students' motivations, values, and attitudes need to be explored further so as to determine long-term strategies that could lead to a fulfillment of the desired outcome, namely, the internationalization of education.

Business communication and public speaking courses may prove to be a natural environment for such strategies since their programs typically contain the issues of cultural differences, audience analysis, and communication strategies. Furthermore, results showed that, despite their cultural differences, students were able to objectively assess the argumentation of Greta Thunberg and agree on its validity owing to the knowledge acquired in public speaking courses. Finally, an international classroom consisting of domestic and international students may significantly facilitate a public as well as a political debate as students of different cultural and social backgrounds may have different attitudes on global issues which they may readily discuss in a safe environment which is the university. 


\section{Literature}

Amossy, Ruth (2000). L'argumentation dans le discours politique: Littérature d'idée, fiction. Paris: Nathan.

Aristotle (1989). Retorika. Zagreb: Naprijed.

Beelen, Jos; Jones, Elspeth (2015). Redefining internationalization at home. In Adrian Curaj et al. (Eds.), The European Higher Education Area: Between Critical Reflections and Future Policies (pp. 59-72). Cham: Springer.

ENEC (2018). European Network for Environmental Citizenship, Defining "Education for environmental citizenship." European Network for Environmental Citizenship. URL: http:/enec-cost.eu/our-approach/education-for-environmental-citizenship/ (June 28, 2020)

Ester, Peter; Simões, Solange; Vinken, Henk (2004). Cultural change and environmentalism: A cross-national approach of mass publics and decision makers. Ambiente \& Sociedade, 7(2), 45-66. doi: https://doi.org/10.1590/S1414-753X2004000200004

European Commission (2020). Statistics. European Commission. URL: https://ec.europa. eu/programmes/erasmus-plus/about/statistics_en (January 7, 2021)

Fielding, Kelly S.; Hornsey, Matthew J. (2016). A social identity analysis of climate change and invironmental attitudes and behaviours: Insights and opportunities. Frontiers in Psychology, 7, article 121, 1-12.

Harrison, Neil (2019). Global activists, global workers or home aloners: Understanding the challenges of internationalisation at home when creating global citizens. In Sandra Kirk et al. (Eds.), Internationalising the Curriculum: Internationalisation at Home and Engaging Academic Staff (pp. 9-22). Nottingham: Nottingham Trent University.

Hodson, Derek (2014). Becoming part of the solution: Learning about activism, learning through activism, learning from activism. In Larry Bencze \& Steve Alsop (Eds.), Activist science and technology education (pp. 67-98). Dordrecht: Springer.

Knight, Jane (2008). Higher Education in Turmoil: The Changing World of Internationalization. Rotterdam: Sense.

Langan, A. Mark; Wheater, C. Philip; Shaw, Emma M.; Haines, Ben J.; Cullen, W. Rod; Boyle, Jennefer C.; Penney, David; Oldekop, Johan A.; Ashcroft, Carl; Lockey, Les; Preziosi, Richard F. (2005). Peer assessment of oral presentations: Effects of student gender, university affiliation and participation in the development of assessment criteria. Assessment \& Evaluation in Higher Education, 30(1), pp. 21-34, doi: $10.1080 / 0260293042003243878$

Leask, Betty (2015). Internationalizing the Curriculum. London: Routledge.

Mitchell, Douglas E.; Nielsen, Selin Yildiz (2012). Internationalization and globalization in higher education. In Hector Cuadra-Montie (Ed.), Globalization: Education and Management Agendas. London: IntechOpen.

Reis, Pedro (2020). Environmental citizenship and youth activism. In Hadjichambis A. et al. (Eds.), Conceptualizing Environmental Citizenship for 21st Century Education. Environmental Discourses in Science Education: Volume 4 (pp. 139-148). Cham: Springer.

Steel, Brent S. (1996). Thinking globally and acting locally?: Environmental attitudes, behaviour and activism. Journal of Environmental Management, 47, 27-36.

Teichler, Ulrich (2017). Internationalization trends in higher education and the changing role of international student mobility. Journal of International Mobility, 1(5), 177-216.

TNS Opinion \& Social (2011). Special Eurobarometer Report 365: Attitudes of European Citizens Towards the Environment. Brussels: European Commission.

Turman, D. Paul; Barton, H. Matthew (2004). Bias in the evaluation process: Influences of speaker order, speaker quality, and gender on rater error in the performance based 
course. Basic Communication Course Annual, 16, article 6. URL: http://ecommons. udayton.edu/bcca/vol16/iss1/6 (January 7, 2021)

United Nations (2019). World Economic Situation and Prospects. New York: United Nations.

Wit, Hans de (2011). Globalisation and internationalisation of higher education. Revista de Universidad y Sociedad del Conocimiento, 8(2), pp. 241-248.

Zoričić, Tena (2018). Negativne vijesti i navike informiranja mladih u Hrvatskoj (Diplomski rad). Fakultet političkih znanosti Sveučilište u Zagrebu.

ZSEM (2021). Mission and Vision. ZSEM (May 31). URL: https://www.zsem.hr/en/ about-us/mission-and-vision/ (June 8, 2021)

Utjecaj internacionalizacije na stavove studenata prema okolišnom aktivizmu

Ivanka Rajh*, Zdravka Biočina**

Sažetak

Ovaj rad istražuje utjecaj internacionalizacije sveučilišta na stavove o okolišnom aktivizmu među studentima koji studiraju na Zagrebačkoj školi ekonomije i managementa. S tim ciljem provedena je anketa kojom se ispitalo mišljenje studenata o okolišnoj aktivistici Greti Thunberg i njezinu govoru na UN-ovu samitu o klimatskim promjenama. Uzorak se sastojao od 99 studenata koji studiraju na hrvatskom i engleskom jeziku. Grupu studenata koji studiraju na engleskom jeziku čine studenti iz Hrvatske te strani studenti koji su redovno upisani i koji su na razmjeni. Istraživačka pitanja pokrila su ulogu jezika, ekološku svijest, dob i obrazovanje u percepciji kvalitete, atraktivnosti, uvjerljivosti i utjecajnosti govora. Rezultati ankete pokazali su da postoje razlike u stavovima studenata tih grupa o tinejdžerskoj aktivistici i njezinu govoru. Iako se studenti iz engleske grupe samoprocjenjuju nešto ekološki osvještenijima od studenata iz hrvatske grupe, govor ocjenjuju znatno bolje od hrvatske skupine $i$ to u svim kategorijama. Statistički značajne razlike između grupa pronadene su samo za pitanja o Gretinu kredibilitetu i atraktivnosti govora. Nadalje, ispitana je i razlika među studentima unutar engleske grupe. Pronađena je statistički značajna razlika između međunarodnih studenata $i$ hrvatskih studenata koji studiraju na engleskom za gotovo sva pitanja iz ankete, osim za pitanje o ekološkoj osviještenosti. Pritom su međunarodni studenti u anketi statistički značajno bolje ocjenjivali Gretu i njezin govor. Na stav hrvatskih studenata o Greti Thunberg i njezinu govoru može utjecati činjenica da globalno zatopljenje još uvijek nije toliko važna tema u hrvatskom javnom diskursu. S druge strane, međunarodna skupina studenata može biti sastavljena od većega broja studenata koje Harrison (2019, 13-14) definira kao globalne aktiviste i koji su općenito zainteresiraniji za globalna pitanja poput klimatskih promjena, a što je moglo utjecati na te razlike.

Ključne riječi: internacionalizacija sveučilišta; okolišni aktivizam; stavovi studenata; percepcija studenata; Greta Thunberg; javni govor

* Doc. dr. sc. Ivanka Rajh, Zagrebačka škola ekonomije i managementa. Adresa: Vukasovićeva ulica 1, 10000 Zagreb, Hrvatska.E-adresa:irajh@zsem.hr

** Dr. sc. Zdravka Biočina, Zagrebačka škola ekonomije i managementa. Adresa: Vukasovićeva ulica 1, 10000 Zagreb, Hrvatska. E-adresa: zbiocina@zsem.hr 